\title{
When Refugees are Women: Emergence of the Issue on the International Agenda
}

\author{
Keiko Osaki
}

\begin{abstract}
Using the latest refugee statistics available from the United Nations High Commissioner for Refugees (UNHCR), the author examines, first, the presence of women in refugee populations. Second, she chronologically reviews the efforts of the United Nations and United Nations agencies to heighten awareness regarding the issue, and to resolve specific problems that refugee women face. Lastly, the special needs for women refugees are identified with implications for possible program interventions.
\end{abstract}

Précis

A l'aide des plus récentes statistiques surles réfugiés émises par le Haut Commissaire des Nations Unies sur les réfugiés, l'auteure du présent article examine d'abord la présence féminine dans la population de réfugiés. Ensuite elle présente chronologiquement les tentatives des Nations Unies et de leurs diverses agences pour accroître la sensibilisation sur la question, et résoudre les problèmes particuliers auxquels les femmes réfugiées font face. Finalement, on procède à une identification des besoins spéciaux des femmes réfugiées ainsi que des implications sur les programmes d'intervention possibles.

Although refugee statistics remain highly problematic in terms of availability and quality, most recent data attest that women constitute over half of the world refugee population. In refugee situations, however, these

Keiko Osaki is a population affairs officer at the Population Division of the United Nations. Her research is concerned with mechanisms of international population mobility from a gender perspective.

The views expressed herein are those of the author and should not be interpreted as necessarily representing those of the United Nations. women tend to bear a disproportionate share of hardship. They become particularly vulnerable to various forms of discrimination, exploitation and abuse.

Unfortunately, the issue of refugee women had received scant attention over the years. It is only recently that the international community has begun to recognize that refugee women have special needs because of their gender. A consensus has emerged that programs regarding protection and assistance for refugees must accommodate these particular needs. These programs must respect their dignity and urge their participation in planning and implementing programs.

\section{The Presence of Women in Refugee Population: Statistical Evidence}

Accurate and precise statistical information is an important tool for planning and formulating refugee assistance programs. But data that would accurately reflect the situation of refugee women are extremely difficult to obtain. Given the fluid nature of refugee populations, their numbers may fluctuate markedly from one point in time to another. As refugees often move in and out the camps without notifying local authorities, statistics from refuge sites remain to be, at best, rough approximations in many countries. Even if the host country could furnish refugee statistics, in many cases no classification is available by basic demographic characteristics such as age and sex.

In response to the call for improvements in information on refugee women, in 1994 the UNHCR for the first time compiled gender specific information on refugees in a cross-national manner and published this information in the Statistical Overview. At that time, the report provided a breakdown of refugee population by sex for only 37 countries of asylum (UNHCR 1994). Slow, but steady improvements have been observed over time in terms of the availability of gender-specific refugee statistics. By 1996, 67 countries could furnish the information on refugee population classified by sex, and a refugee population of 4.7 million persons were reported (UNHCR 1997). These data represent about 31 percent of the world refugee population which was estimated at 15.4 million at the end of 1996.

Table 1 presents the latest refugee statistics broken down by sex and age, and Figure 1 graphically displays the proportion of women in a refugee population in a country or area of asylum, according to the geographical region. Assuming that these statistics represent the gender distribution of the refugee population worldwide, women appear to constitute 53 percent of the world refugee population (see Table 1). That is to say, over half of the refugees in the world were women. Figure 1 also illustrates that, regardless of geographical region, women refugee are as numerous as male refugees. Women make up 40 to 60 percent of the total refugee population in 50 out of 67 countries or areas examined.

In some countries, the presence of women is noticeably high. The proportion of women exceeded more than three-fifths of the total in countries such as Libya (70\%), Uganda (65\%), Niger (64\%), Gambia (62\%), Turkmenistan $(60 \%)$, and Mauritania $(60 \%)$, in order of magnitude. On the other end of the scale, low presence of women in the refugee population was characteristic of countries such as Cuba (16\%), Greece (20\%), Nepal $(21 \%)$, Saudi Arabia (25\%), Gabon $(27 \%)$ and Malaysia (28\%). Women are often more numerous than men in refugee populations when men are

Continued on page 12

Refuge, Vol. 16, No. 4 (October 1997) 
Table 1: Refugee Population and the Percent Distribution of Female Refugees in Country of Asylum, as of the End of 1996

\begin{tabular}{|c|c|c|c|c|c|c|}
\hline \multirow[b]{2}{*}{$\begin{array}{l}\text { Country of } \\
\text { asylum }\end{array}$} & \multirow[b]{2}{*}{$\begin{array}{c}\text { Total } \\
\text { number of } \\
\text { refugees }\end{array}$} & \multirow{2}{*}{$\begin{array}{l}\text { Number of } \\
\text { refugees } \\
\text { whose age } \\
\text { and sex were } \\
\text { identified }\end{array}$} & \multicolumn{4}{|c|}{ Percentage of } \\
\hline & & & $\begin{array}{c}\text { Women } \\
\text { all } \\
\text { ages }\end{array}$ & $\begin{array}{l}\text { Women } \\
\text { under } 18 \\
\text { years old }\end{array}$ & $\begin{array}{c}\text { Women } \\
18-59 \\
\text { years old }\end{array}$ & $\begin{array}{c}\text { Women and } \\
\text { children } \\
\text { under } \\
18 \text { years }\end{array}$ \\
\hline Libya & 7,747 & 3,409 & 70 & 15 & 40 & 83 \\
\hline Uganda & 264,294 & 264,179 & 65 & 31 & 31 & 84 \\
\hline Niger & 25,845 & 4,075 & 64 & 45 & 19 & 78 \\
\hline Gambia & 6,924 & 1,893 & 62 & 28 & 31 & 75 \\
\hline Turkmenistan & 15,580 & 680 & 60 & 40 & 20 & 82 \\
\hline Mauritania & 15,880 & 15,872 & 60 & 30 & 19 & 86 \\
\hline Croatia & 165,395 & 165,395 & 58 & 14 & 30 & 72 \\
\hline Pakistan & $1,202,703$ & $1,202,703$ & 58 & 27 & 31 & 80 \\
\hline $\begin{array}{l}\text { Democratic Republic } \\
\text { of Congo }^{\mathrm{a}}\end{array}$ & 675,973 & 983 & 55 & 22 & 30 & 76 \\
\hline Jordan & 874 & 840 & 55 & 21 & 32 & 79 \\
\hline Togo & 12,589 & 12,387 & 54 & 29 & 24 & 83 \\
\hline Cameroon & 46,407 & 2,583 & 54 & 19 & 34 & 73 \\
\hline Cote d'Ivoire & 327,696 & 195,482 & 53 & 36 & 17 & 87 \\
\hline Congo & 20,451 & 5,301 & 53 & 31 & 21 & 79 \\
\hline Burundi & 981 & 606 & 53 & 23 & 29 & 70 \\
\hline Yugoslavia & 563,215 & 566,275 & 53 & - & - & - \\
\hline Senegal & 65,044 & 64,030 & 53 & 26 & 24 & 79 \\
\hline Sierra Leone & 13,532 & 11,779 & 52 & 31 & 21 & 81 \\
\hline Yemen & 53,546 & 27,371 & 52 & 26 & 24 & 74 \\
\hline Guinea-Bissau & 15,401 & 15,401 & 52 & 25 & 26 & 79 \\
\hline Botswana & 214 & 214 & 51 & 34 & 17 & 65 \\
\hline Bangladesh & 30,692 & 30,625 & 51 & 30 & 20 & 81 \\
\hline Guinea & 663,854 & 663,838 & 50 & 25 & 24 & 78 \\
\hline Chile & 313 & 175 & 50 & 34 & 11 & 71 \\
\hline Afghanistan & 18,775 & 17,936 & 50 & 20 & 25 & 70 \\
\hline Benin & 5,960 & 5,419 & 50 & 19 & 30 & 67 \\
\hline Mexico & 34,569 & 34,569 & 50 & - & - & - \\
\hline Macedonia & 5,089 & 3,989 & 49 & 17 & 27 & 69 \\
\hline India & 233,370 & 82,054 & 49 & 6 & 6 & 55 \\
\hline China & 290,100 & 290,045 & 49 & 20 & 29 & 68 \\
\hline Angola & 9,381 & 9,341 & 49 & 25 & 22 & 81 \\
\hline Mali & 18,234 & 17,495 & 49 & - & - & - \\
\hline Turkey & 8,166 & 3,548 & 48 & 16 & 28 & 65 \\
\hline Ethiopia & 390,528 & 349,449 & 48 & 25 & 19 & 76 \\
\hline
\end{tabular}




\begin{tabular}{|c|c|c|c|c|c|c|}
\hline \multirow[b]{2}{*}{$\begin{array}{l}\text { Country of } \\
\text { asylum }\end{array}$} & \multirow[b]{2}{*}{$\begin{array}{c}\text { Total } \\
\text { number of } \\
\text { refugees }\end{array}$} & \multirow{2}{*}{$\begin{array}{l}\text { Number of } \\
\text { refugees } \\
\text { whose age } \\
\text { and sex were } \\
\text { identified }\end{array}$} & \multicolumn{4}{|c|}{ Percentage of } \\
\hline & & & $\begin{array}{c}\text { Women } \\
\text { all } \\
\text { ages }\end{array}$ & $\begin{array}{c}\text { Women } \\
\text { under } 18 \\
\text { years old }\end{array}$ & $\begin{array}{c}\text { Women } \\
18-59 \\
\text { years old }\end{array}$ & $\begin{array}{c}\text { Women and } \\
\text { children } \\
\text { under } \\
18 \text { years } \\
\end{array}$ \\
\hline Iraq & 112,957 & 38,959 & 48 & 25 & 21 & 76 \\
\hline Iran & $2,030,359$ & 86,151 & 48 & 28 & 19 & 78 \\
\hline Nigeria & 8,486 & 6,284 & 48 & 22 & 25 & 69 \\
\hline Kenya & 223,640 & 153,109 & 47 & 24 & 23 & 73 \\
\hline Peru & 663 & 246 & 47 & 4 & 32 & 55 \\
\hline Burkina Faso & 28,381 & 28,024 & 47 & 21 & 23 & 74 \\
\hline Tanzania & 498,732 & 89,542 & 46 & 25 & 21 & 73 \\
\hline Russian Federation & 205,458 & 3,710 & 46 & 22 & 20 & 69 \\
\hline Ecuador & 211 & 93 & 45 & 17 & 27 & 68 \\
\hline France & 151,329 & 123,579 & 45 & - & - & - \\
\hline Tajikistan & 1,166 & 339 & 45 & 10 & 32 & 57 \\
\hline Syria & 27,759 & 3,099 & 44 & 25 & 15 & 71 \\
\hline Namibia & 2,204 & 2,027 & 44 & 22 & 21 & 63 \\
\hline Eritrea & 2,108 & 1,982 & 44 & 19 & 24 & 66 \\
\hline Central African Republic & 36,564 & 34,961 & 44 & 24 & 19 & 74 \\
\hline Somalia & 700 & 569 & 44 & 17 & 27 & 61 \\
\hline Romania & 269 & 51 & 43 & 18 & 24 & 63 \\
\hline Argentina & 10,430 & 404 & 42 & 9 & 33 & 46 \\
\hline Belgium & 36,060 & 36,080 & 42 & - & - & - \\
\hline Ghana & 35,617 & 35,436 & 40 & 17 & 18 & 68 \\
\hline Hong,Kong (China) & 6,875 & 1,345 & 38 & 12 & 26 & 51 \\
\hline Swaziland & 575 & 347 & 38 & 24 & 14 & 63 \\
\hline Kuwait & 3,831 & 3,720 & 36 & 12 & 21 & 50 \\
\hline Bolivia & 698 & 473 & 36 & 11 & 25 & 48 \\
\hline Colombia & 220 & 74 & 34 & 9 & 22 & 57 \\
\hline Lebanon & 2,408 & 1,858 & 33 & 14 & 16 & 49 \\
\hline Mozambique & 198 & 140 & 31 & 17 & 14 & 47 \\
\hline Malaysia & 199 & 57 & 28 & 12 & 16 & 42 \\
\hline Gabon & 798 & 236 & 27 & 14 & 13 & 38 \\
\hline Saudi,Arabia & 9,852 & 9,852 & 25 & 15 & 9 & 41 \\
\hline Nepal & 126,815 & 2,125 & 21 & 10 & 10 & 48 \\
\hline Greece & 5,780 & 257 & 20 & 6 & 6 & 30 \\
\hline Cuba & 1,703 & 1,577 & 16 & 0 & 16 & 21 \\
\hline Grand total & $8,782,367$ & $4,734,626$ & 53 & 21 & 21 & 73 \\
\hline
\end{tabular}

Source: United Nations High Commissioner for Refugees, 1996 Statistical Overview (Geneva, 1997).

a The former Zaire. 
Figure 1: Proportion of Women in Total Refugee Population by Geographical Region, Early 1997, (\%)

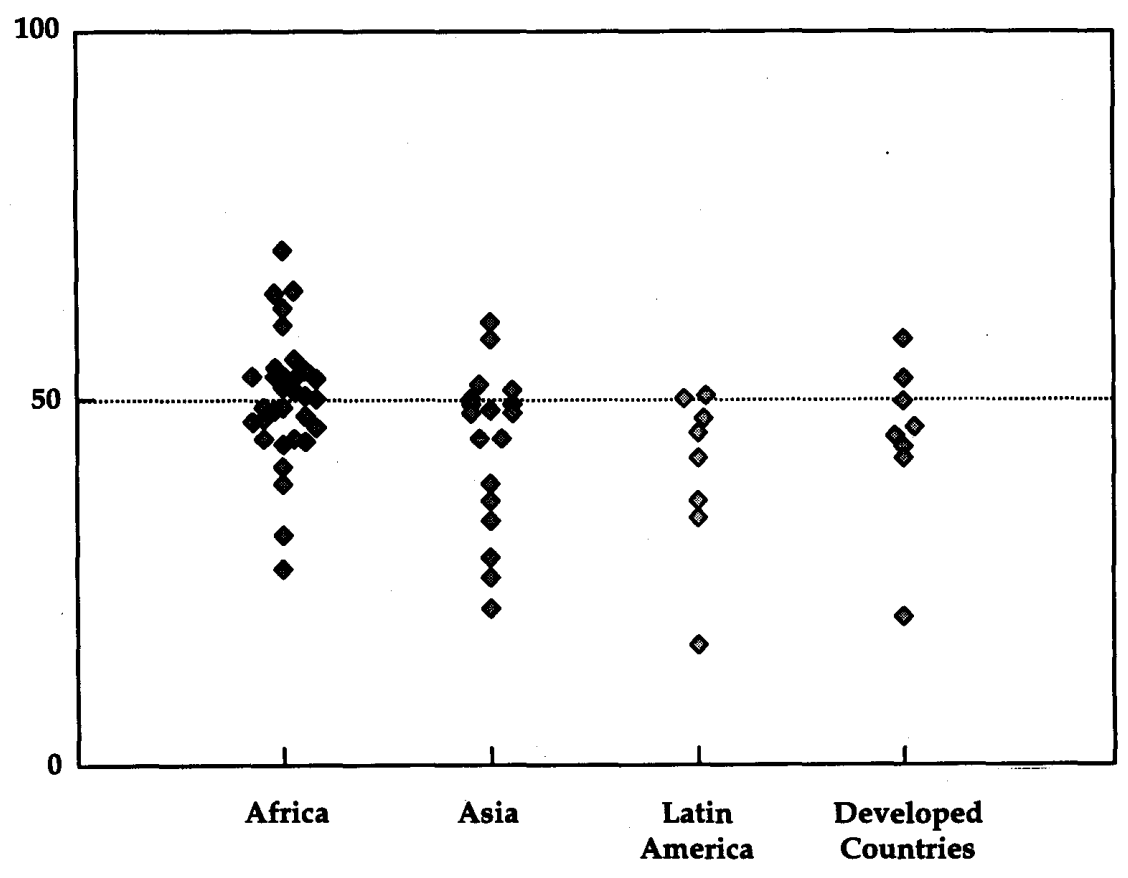

Source: Table 1.

Continued from page 9

heavily involved in war or civil strife. On the other hand, as seen in the example of Cuba, the share of women in refugee population is likely to be small when the figure comprises predominantly of political refugees. In general, however, one should exercise caution in interpreting those data indicating the extremely high or low representation of women. Those figures tend to be generated from only a subset of the total refugee population and they may not represent the true sex distribution of the whole refugee population in a country. Indeed, as seen in the difference in the first and second columns of Table 1, countries such as Niger, Gambia, Turkmenistan, Malaysia, Gabon, Nepal, and Greece could not furnish the information on the sex and age of the vast majority of their refugee populations.

The age distribution of refugee women varies across countries of asy- lum as seen in Table 1 which presents the information on the proportion of girls (under 18 years old), adult women (18-59 years old) and elderly women ( 60 years and over) in the refugee population. The proportion of girls in refugee population greatly varied from almost none in Cuba to a high of 45 percent in Niger. In many developing countries, refugee population comprised relatively high proportion of girl refugees, representing the population of high fertility countries. At the global level, the girl refugees constituted about a quarter or 26 percent of the total refugee population. Adult females are the equally significant component of refugee population. Approximately, one in every five refugees in the world was adult woman, while the level greatly differed from country to country. In contrast to girl and adult female refugees, the presence of elderly women in refugee population was notably low, with the exception of few countries. Lastly, the data shown in the last column of the table confirmed the widely accepted view that women and children account for approximately 70 to 80 percent of the world refugees (as do men and children together).

\section{Efforts of the United Nations and \\ UN Agencies to Improve the Situation of Refugee Women}

As well-acknowledged, the United Nations' effort to launch the United Nations Decade for Women: Equality, Development and Peace (1975-85) helped to bring women's issues to the forefront of world attention. The United Nations' first specific focus on refugee women goes back to its middecade meeting held in Copenhagen in 1980. Recognizing that women and children form the bulk of the refugee populations and have particular needs, the Copenhagen meeting ad- 
dressed the responsibility of states to bring to the justice those who abuse refugee women and children and to take steps to prevent such abuses (United Nations 1995a). The UNHCR, in cooperation with other concerned UN agencies, was urged to establish programs necessary for dealing with the special needs of displaced and refugee women. Thus, the stimulus to shed light on the plight of refugee women arose in the context of advancement of women's status, not from efforts to find solutions to refugee or migration problems.

While the Copenhagen meeting opened the door to the issue of refugee women in the following years, it was the World Conference to Review and Appraise the Achievements of the UN Decade for Women held in Nairobi in 1985 that gave an impetus for strategic action. In the "Nairobi Forward Looking Strategies for the Advancement of Women," adopted at the end of the decade, the issue of refugee and displaced women and children was raised again. The international community was requested to continue to provide relief assistance as a humanitarian responsibility and to launch special relief programs, taking into account the needs of refugee women and children in countries of first asylum (United Nations 1995b).

By this time, interest in the issue of refugee women had increased within the UNHCR. In 1985, the Executive Committee of the UNHCR at its 36th session included the issue of refugee women on its agenda for the first time. The Conclusion No. 39 entitled "Refugee Women and International Protection," stressed the need for UNHCR and host government to give particular attention to the protection of refugee women. It was agreed that the standards of refugees defined in the existing international refugee instruments were rather general, applying equally to refugee women and refugee men, and did not take account of the special protection problems with which refugee women are confronted (Siemens 1988). The meeting was particularly important in recognizing that women who face harsh and inhumane treatment for transgressing the social mores of their societies may be considered a "particular social group" within the definition of a Convention refugee.

In 1988, the Executive Committee of UNHCR adopted a conclusion entitled "Refugee Women," which elaborated further on the special vulnerability of refugee women and the particular problems that they face. It also underlined the importance of the full participation of women in refugee assistance programs as agents as well as beneficiaries of programs on their behalf. Within the same year, UNHCR established a Steering Committee on Refugee Women in order to define, oversee the assessment, and strengthen existing policies and programs in favour of refugee women. The integration of gender factors into the overall design of a refugee assistance program was also encouraged in the People Oriented Planning Training Programme (POP), the special staff training program that UNHCR launched in 1989.

In July 1990, in order to improve the UN system's responsiveness to the needs of refugee women, the Division for the Advancement of Women of the UN organized the Expert Group Meeting on Refugee and Displaced Women and Children, involving UNHCR, UNIFEM, UNICEF and other relevant organization and various NGOs. The Expert Group stressed that the civil, political, economic, social and cultural rights of refugee and displaced women and children should be reaffirmed and backed by laws, policies and programs (United Nations 1991). Among other recommendations, the Group urged for the improvement of assistance for refugee women in the areas of health, education and employment in both short and long-term. The Commission of the Status of Women at its thirtyfifth session adopted many of the Expert Group's recommendations.

Providing refugee women with better protection is not just a question of policy. It also depends largely on the attitude of staff members who actually offer it-most importantly field officers and representatives. In 1991,
UNHCR issued Guideline on the Protection of Refugee Women to help the staff of UNHCR and its implementing partners to identify the specific protection issues, problems and risks that refugee women face (UNHCR 1991). Recognizing that prevention is preferable to cure, the guidelines point to needs for refugee women's safety and well-being and suggest various measures to be taken to improve the protection of refugee women.

The issue of refugee women also cannot be isolated from that of human rights. In response to the calls from women's organizations around the world, the issue of women's rights was chosen as a major theme of the World Conference on Human Rights held in Vienna in 1993. At the Conference, violations of women's rights in situations of armed conflict were considered as humiliations to the most fundamental principles of internationally recognized human rights and humanitarian laws. The report adopted at the Conference, in its specific section on refugee and displaced women, stress that "in addition to the fears and problems which they share in common with all refugees, women and girls are vulnerable to gender-based discrimination and gender-specific violence and exploitation."

Subsequent events in the former Yugoslavia, Somalia and Rwanda in the early 1990s have renewed attention to the needs to prevent and respond to sexual violence against refugees, especially refugee women. Based on detailed recommendations by field workers experienced with the rape and piracy attacks on refugees, UNHCR developed another set of action-oriented guidelines for preventing and responding to sexual violence in 1995 (UNHCR 1995). It aimed to provide refugee workers with practical advice on the medical, psychological and legal ramifications of sexual violence. It was widely distributed not only within UNHCR, but also to non-governmental organizations and other field offices.

In addition to the issues of sexual violence, the issue of the provision of reproductive health in the process of 
refugee assistance have received growing attention in recent years. The International Conference on Population and Development, held in Cairo in 1994 declared in its "Programme of Action" that reproductive health care and family planning are vital human rights (United Nations 1995c). Recognizing the inadequacy or lack of such health services in field operations, relevant UN agencies have taken steps to make.comprehensive reproductive health services a reality. UNHCR and UN Population Fund (UNFPA) have embarked on a series of joint activities to promote reproductive health in refugee situations and developing a practical guidance manual for the field.

\section{Special Needs of Refugee Women}

The review of refugee statistics in the first section of this paper attested that the number of refugee women is almost equal to that of male counterparts in a majority of countries. Refugee women, however, tend to bear a disproportionate share of the hardships. Many of the problems that refugee women face are by no means new nor unique: they are possibly a routine element of the persecution of women. But such traditional disadvantages of women are likely to be intensified in refugee situations.

A large number of refugee families experience loss of or separation from family members before or during the flight. Thus, family structure, which is usually a basis of protection, often changes dramatically in the chaos of emergencies. Many refugee women become widows or heads of household. Being stripped of the protection by husbands or supports of close kin, they are expected to take on new responsibilities for their family. But, typically with dependent children and no source of income, they are prone to be dependent on external support structures and vulnerable to exploitation. While refugee women themselves make efforts to adopt to an alien environment, they need protection and assistance that reflect their gender. Those specific needs of women include legal protection, physical protection, pro- tection from sexual violation and better provision of services.

\section{Legal Protection}

Determination of refugee status is fundamental for protecting and assisting refugee population. Women, however, often face difficulties in establishing their own refugee status. The definition of "refugee" does not include persecution based on gender as a group for obtaining refugee status. In recent years, increased awareness of sexual violence against women has led a few countries to recognize gender-based claims for asylum. Furthermore, UNHCR encourages countries to consider female genital mutilation, forcible abortion or sterilization as grounds for refugee status. Currently, however, only Canada and the United States have integrated these elements into their refugee policies.

Even where the gender-based persecution falls into one of the defined area, women often experience difficulties in substantiating their claim. Many women are not willing to speak openly about the circumstances that caused them to flee, particularly when they have been sexually abused and the interviewers are men. It is therefore very important to use a variety of gender-sensitive techniques to obtain information from women during the status determination process (UNHCR 1995).

Refugee women need to have full understanding about their rights as refugees in order to maximize their entitlement. Refugee women, however, often experience difficulty in registering with the proper authorities and obtaining documentation of their refugee status and eligibility for assistance. In some situations, only male heads of household are given documentation and women are not routinely provided documents proving their legal status in the country of asylum. Other constraints include physical and logistic difficulties in reaching the authorities responsible for registration, particularly in cultures that do not permit women to interact with strangers.

\section{Protection from Physical Violence}

Violation of physical security is one of the most serious problems affecting refugee women. Physical abuse or violence against women are common in most societies. But the path of refugees enhance such dangers. There are an increasing number of reports that women have been victimized by pirates, border guards and soldiers with whom they come in contact during the flight. Unaccompanied refugee women and adolescent girl refugees are especially vulnerable to these forms of aggression as compared to those living under the protection of their families or communities.

Violence against women does not necessarily abate even after refugee women reach an asylum country. In many refugee camps, the facilities are often overcrowded and shared by many unrelated families, thereby increasing the potential for attacks and aggression. The enforced idleness, boredom frustration and despair that permeates many refugee camps are said to be grounds for such violence. Thus, the programs for refugee assistance must ensure great safety of refugee women. Special measures which need to be implemented include the provision of security patrols, appropriate medical services for victims, and emergency relocation whenever necessary. In some cases, the best solution for a woman who has been a victim of violence may be to remove her from the site of the violence.

\section{Protection from Sexual Exploitation/Prostitution}

Sexual violence and exploitation are shockingly frequent experiences for refugee women in all stages of the refugee situation-before and during flight, and in refugee camps. As recent atrocities in Bosnia and Herzegovina indicate, rape can be wielded as an instrument of militarized masculinized nationalism (Enloe 1995). The use of rape or other forms of sexual violence as a mean of terrorizing the community was evidenced also in Haiti, Myanmar, Rwanda, Somalia and Sri 
Lanka in recent years. In a much large number of countries, border guards, security officers and military personnel routinely exploit their positions of power by demanding sex from refugee women or by forcing them into prostitution. At the same time, refugee women are also exposed to the risk of such aggression even from members of their own community in adverse situations, where established social norms and structures have been destroyed by sudden displacement. Those women who were victimized or who became prostitutes often experienced unwanted pregnancies and/or were infected with sexually transmitted diseases.

In order to combat such incidents and to provide victims with proper assistance, the problem of sexual violence and exploitation need to be addressed in a more explicit manner. The incidence of rape and other forms of sexual assaults are possibly more prevalent than actually reported or identified. Given the sensitive nature of the incidents, victimized women are reluctant to discuss the subject with the authorities, thereby preventing themselves from receiving assistance that they deserve. These women may also be unwilling to report such incidents because of the fear of retaliation or social stigma. Thus, the full scale of incidents remains to be revealed.

UNHCR (1995) suggests that one of the most effective ways to identify cases of sexual violence is to facilitate the establishment of women's groups and associations, thereby giving individual women a channel to report attacks. It is also important to give special priority to expand protection for refugee women by employing female protection officers in border units, as well as inside refugee camps and other places of settlement. With assured privacy and safety, culturally sensitive counseling should be offered to the refugee women who have been victims of sexual violence.

\section{Better Access to Services}

Refugee women have a wide range of service needs as do refugee men. Ac- cess to food, health services, education and training and economic opportunities are among the key issues. Refugee programs thus need to ensure that refugee women have equal access to all these services and opportunities that they deserve.

Women tend to be passive recipients of food and other distributed items. As a result, they often suffer from inadequate diets. Malnourished women who are pregnant or lactating are unable to provide sufficient nutrition to their children. Such common problems in refugee camps partly arise from the fact that food distributors, including international organizations and host Governments, have an inadequate or limited understanding of the nutritional needs of refugee women and of the actual circumstances of women who cook and feed. It is therefore important to review the traditional male-dominated food distribution system and design a new distribution procedure by involving refugee women at the planning stage of distribution. Distributing food directly to women can also increase the likelihood that adequate food will reach the whole refugee population.

Similarly, increasing access of refugee women to basic health and medical services is important both to their own health and to that of their families, as women are the primary providers of health care to the family members. Refugee women are often exposed to various health risks often in overcrowding and poor sanitary conditions. For instance, water-borne disease are prevalent among refugee women who are the primary collectors of water. Women may also face particular mental health problems arising from loss of traditional support systems and difficulties in adjusting to life in alien environment where language, culture and living condition are all unfamiliar. Unfortunately, however, health services targeted at the needs of women are often limited, especially in a refugee emergency. The users of inpatient facilities tend to be dominated by men. The absence of female health workers or practitioners in refugee communities have also been one of the major impediment to health care. In many situations, health facilities are located far away so that refugee women cannot reach them easily.

The virtual absence of the comprehensive reproductive health services also present another major threat to the health of refugee women. Refugee women, as do all other women, need basic care for safe birth, family planning information and services, the prevention and treatment of sexually transmitted diseases and HIV/AIDS, treatment of complications from female genital mutilation (FGM) and unsafe abortion, and other aspects of reproductive health. The introduction of these reproductive health care services into refugee settings remains a challenging task, especially when social and cultural barriers inhibit open discussion on the topic.

Lastly, access by refugees to education is generally poor. The situation is possibly worse for refugee girls whose rights tend to be totally neglected. Refugee girls' chances to attend schools is likely to be low as they are often required to assist with daily household chores-collecting water or firewood, washing, cooking and child care. The income-generation activities for refugee women are also equally limited, despite the fact that many refugee women are heads of households and must assume full economic responsibility. Availability of skill training or job opportunities are often either targeted at men or require minimum level of education or skills that many refugee women do not possess. Culture in the country of origin or destination may also constrain refugee women from working outside of the home.

\section{Conclusion}

Data that would accurately portray the plight of refugee women continue to be limited. But refugee statistics most recently available suggest that women constitute over half of the world refugee population. In refugee situations, these women suffer from exacerbated hardships, and their marginalized sta-

Refuge, Vol. 16, No. 4 (October 1997) 
tus is likely to be reinforced. Based on an explicit recognition of this fact, the United Nations and United Nations agencies have focused its growing attention on the particular circumstances and special needs of women refugees. Countries of asylum have been urged to grant refugee status for those women who are under persecution based on gender. Refugee protection and assistance programs have been designed to accommodate special needs of refugee women, especially in terms of physical safety, protection from sexual violence, and provision of services.

It should be noted, however, that the program needs of refugee women may not be properly addressed by treating them as a simple target group. As shown in the first section of the paper, even basic demographic features of refugee population (e.g., age distribution) differ significantly across countries of asylum. It suggests that needs of refugee women are not all the same. As not all refugee women find themselves in identical circumstance, different protection and assistance strategies for refugee women may be necessary for each country of asylum. At the same time, there are also needs for complementary activities targeted at refugee men. One should be reminded that while refugee women have special needs that reflect their gender, the problems confronting refugee women are, in many case, also shared by their counterparts-refugee men.

Obviously, the adoption of the policy on refugee women by the UN and other UN agencies will contribute to solving only part of the problem. It is necessary that a wide range of institutions, including both government and non-governmental organizations, adopt similar policies and strategies to seek durable solutions for the situation of refuge women.

\section{References}

Enloe, Cynthia. 1995. "Feminism, Nationalism and Militarism: Wariness without Paralysis." In Feminism, Nationalism and Militarism, edited by Constance Sutton, 13-32. Arlington, VA: Association for Feminist Anthropology/American Anthropological Association.

Siemens, Maria. 1988. "Protection of Refugee Women." Refugees (Geneva), no. 56, 21-22.

United Nations. 1991. Peace: Refugee and Displaced Women and Children: Report of the Secretary-General. United Nations Economic and Social Council, Commission on the Status of Women. United Nations publication, E/CN.6/1991/4

- 1995a. "Report of the World Conference of the United Nations Decade for Women: Equality, Development and Peace," held in Copenhagen, 14-30 July 1980. In The United Nations and the Advancement of Women: 1945-1995, Sales No. E.95.I.29. New York: UN

-1995b. "Report of the World Conference to Review and Appraise the Achievements of the United Nations Decade for Women: Equality, Development and Peace," held in Nairobi, 15-26 July 1985. In The United Nations and the Advancement of Women: 1945-1995, Sales No. E.95.I.29. New York: UN.

_. 1995c. "Population and Development: Programme of Action Adopted at the International Conference on Population and Development," held in Cairo, 5-13 September 1994. ST/ESA/SER.A.149.

UNHCR. 1991. Guidelines on the Protection of Refugee Women. Geneva: UNHCR.

-1994. Population of Concern to UNHCR:A Statistical Overview 1993. Geneva: UNHCR.

- 1995. Sexual Violence against Refugees: Guidelines on Prevention and Response. Geneva: UNHCR

-1997. Population of Concern to UNHCR 1996 Statistical Overview. Geneva: UNHCR. 口

\section{Centre for Refugee Studies ON-Line}

WebSite: http://www.yorku.ca/research/crs Email: refuge@yorku.ca

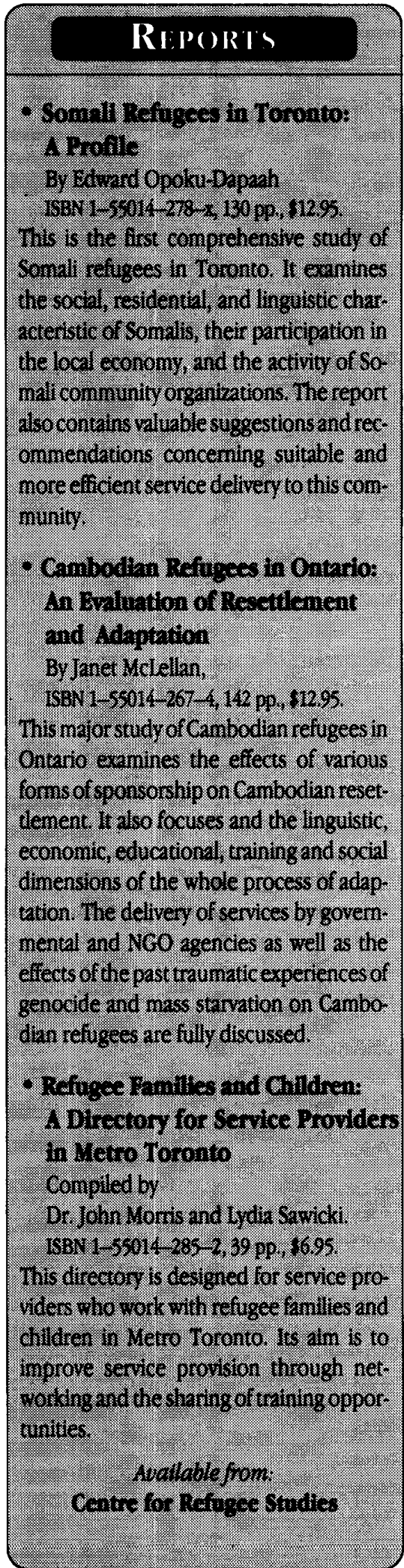

Somull Refuges in Toronto: s. Frotle By Edward Opoku-Dapaa

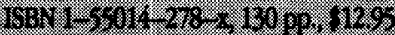

This is the hrst comprohensive suidy of Somil refiges in Toronio. If Eemines

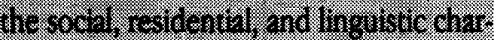

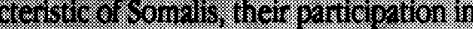

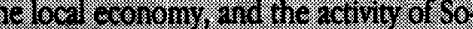
repor Oก: nore eniciear service delmer to his com กับกับ

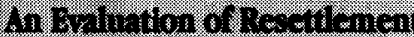

and thentith

By. Tone TClellan

ingeesin (2) dement 1 iso boeuses and he Inguistic economic educational trinmgand socki dimensions of the whole process of adis. aton. The delivery of services by govern nenal and NCO agencies as well as: hie efrects of the past traumatic erperiences. gencorite and hats sterwtion on Cambe

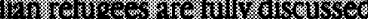

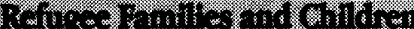

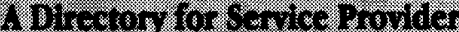
h Tora Tornth Compledib

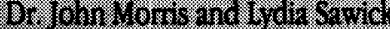
18817 1-53014, $285-2,39$ po. 1695

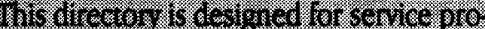

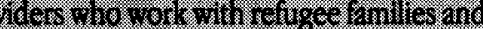
(5) ing op301

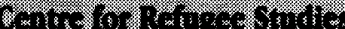

$1<$

(C) Keiko Osaki, 1997. This open-access work is licensed under a Creative Commons Attribution-NonCommercial 4.0 International License, which permits use, reproduction and distribution in any medium for non-commercial purposes, provided the original author(s) are credited and the original publication in Refuge: Canada's Journal on Refugees is cited. 